\title{
Linkages between Bio-Resources and Human Livelihood: A Case Study of Adi Tribes of Mirem Village, Arunachal Pradesh (India)
}

\author{
Gibji Nimachow', Tahong Taga², \\ Hui Tag $^{3} \&$ Oyi Dai ${ }^{4}$
}

\begin{abstract}
The living of man in all societies is largely guided by the availability or otherwise of natural bio-resources. However, the tribal people who are regarded as in the primitive stage and experiencing slow pace of development have a high degree of dependence on the natural resources for their livelihood. Bio - resources consist of all biotic components of environment, which have utility and function in satisfying the individual wants as well as social wants of man. Recently, the importance of the study on man and nature relationship has gained momentum globally and has emerged as main concern for both the developed and developing nations worldwide. As such, the tribal dominated areas by virtue of having the higher percentage of forest cover have become prime area for research in the world context for sustainable use of bio-resources.

The State of Forest Report, 2003 has placed Arunachal Pradesh second after Mizoram in terms of forest coverage with 68, $019 \mathrm{sq}$. $\mathrm{km}$. under forest cover. An analysis of the linkages between the bio - resources and human livelihoods may prove significant and helpful in attaining the first rank in the total coverage of forests in the country. The Adi tribe is a major tribal group of Arunachal Pradesh who mostly inhabit East, West and Upper Siang districts. An assessment of linkages of human livelihood and the bioresources in the Adi inhabited area proved to be helpful in the sustainable management of natural resources. A household survey with the help of suitable structured questionnaire was conducted for Mirem village. Personal interview with the village elders was an important tool for the final analysis. The study finds that these people are forest lovers and they are strongly abated with their existing forests. The traditional folk tales, festivities and myths are strongly linked with nature and deeply influenced by the forest ecology and environment. Economic activities, material culture, food habits, house-building materials, ritual performances and herbal medicine all are collected from the forests. The study found that these people are highly dependent on the bio-resources for their livelihood even in this age of scientific and technological development.
\end{abstract}

Key Words: Bio-resources, livelihood, Adi tribes, Man-nature relationship, Sustainable natural resources management, Forest cover, Material culture, Herbal medicine.

\footnotetext{
${ }^{1}$ Lecturer, Department of Geography, Rajiv Gandhi University, gibji26@yahoo.co.in

${ }^{2}$ Research Scholar, Department of Geography, Rajiv Gandhi University, tahongtaga@yahoo.com

3 Lecturer, Department of Botany, Rajiv Gandhi University, huitag@yahoo.co.in

${ }^{4}$ Research Scholar, Department of Botany, Rajiv Gandhi University, oyidai07@yahoo.com
} 


\section{Introduction}

From the beginning of human civilization, primitive human ancestors used to live in the deep jungle and were amiably nurtured by the nature. The degree of their association with the nature signifies the status of change from a rural to urban society. Tribal people form an important component of the natural ecosystem in which they are in a multiplex relationship among population of organisms for sustaining their livelihood within their habitat. The history of human development starts from their intimate association with the natural resources since time immemorial. The bio-resources which forms a major component of the natural resource, occupy a central position in tribal culture and economy. The tribal way of life is very much dictated by the nature right from the birth to death. The nature is not only their home, but also they always like and live in harmony with nature. Most of the tribes living in forests, hills, and mountains are practicing simple mode of production and have socio-political structure and religious system of their own which revolves round the surrounding natural ecosystem.

The Adi tribes are a major collective tribe living in the Himalayan hills of Arunachal Pradesh (in northeastern India), and they are found in the temperate and sub-tropical regions within the districts of West Siang, East Siang, Upper Siang, Upper Subansiri and Dibang Valley. The literary meaning of "Adi" is the Hill or mountain dwellers. The tribe consists of number of sub tribes viz. Padam, Minyong, Pasi, Bori, Bokar, Karko, Milang, Ramo, Pangi, Shimong, Ashing, Tangam, etc. They speak a language belonging to the Tibeto-Burman family. They are believed to be the descendants of the Abo-Tani (Abo- Father; Tani- Man). The major festivals of these people are Aran, Solung, Etor and Yakjong. Like many other tribal groups, the Adi tribes also largely depend on the bio-resources for their livelihood. The living of the people is intimately linked with the bio-resources. They are dependent on the nearby forest for their daily uses. Various types of timbers, bamboos, canes, roots, leaves and fruits of medicinal value and the bark of trees are commonly used. They have faiths and beliefs linked with these resources. However, in the recent days marked changes have been seen in the relationship of people and bio-resources. The social, cultural and religious life of the Adi tribe of Arunachal Pradesh is largely determined by the environmental conditions. The social customs, beliefs, faith, tradition, culture, etc. reflect the imprint of the nearby forest resources.

\section{Study Area}

The study area is just $22 \mathrm{Km}$ away from Pasighat, the district headquarters of East Siang district. The latitudinal and longitudinal extension of the village is roughly in between $27^{\circ} 56^{\prime}$ $06^{\prime \prime} \mathrm{N}$ to $27^{\circ} 57^{\prime} 43^{\prime \prime} \mathrm{N}$ and $95^{\circ} 11^{\prime} 44^{\prime \prime} \mathrm{E}$ to $95^{\circ} 12^{\prime} 43^{\prime \prime} \mathrm{E}$. It is one of the important villages under Bilat circle of East Siang District, Arunachal Pradesh. It has the largest number of households and total population as per the Census of 2001. The village was shifted from Mishing (former) to Mirem (present) in the year 1948. The name of the village Mirem has been derived from two Adi terms ASI-MIREM, Asi meaning water and Mirem meaning rich. As the name suggests the village has number of natural source of drinking water in its vicinity. According to the household survey conducted in the year 2008, the village consists of 253 households (household size of 6.3). Out of the total households the Adi Minyong sub tribe has $86.6 \%$ household, Gallong sub tribe occupies 5.06\% household, Adi Pasi sub tribe has $4.08 \%$ 
household and 3.7\% households are occupied by the Adi Pangi sub tribe. Majority of the people believe in Donyi - Poloism, which is a type of animism. About $57.6 \%$ of the households believe in the traditional Donyi-Polo religion, $26.3 \%$ beliefs in Christianity and rest of $16 \%$ believes in other religions. As per 2001 census the total population of the village is 1605 , out of which male constitutes 822 and female 783 . The sex ratio is 953 female per thousand male which is higher than the sex ratio of the district, i.e. 937. The total scheduled tribe population of the village is $1473(91.8 \%) 132$ others (labourers, nepalis, employees, etc.) and no scheduled caste population. The literacy rate is $68.3 \%$, which is higher than the literacy rates of East Siang district $(61.22 \%)$ and the state $(54.74 \%)$ as per 2001 census. The male literacy rate of $76.1 \%$ is higher than the female literacy rate of $60.4 \%$. However, the gender gap in literacy rate is only $15.7 \%$ which is less in comparison to other parts of the state.

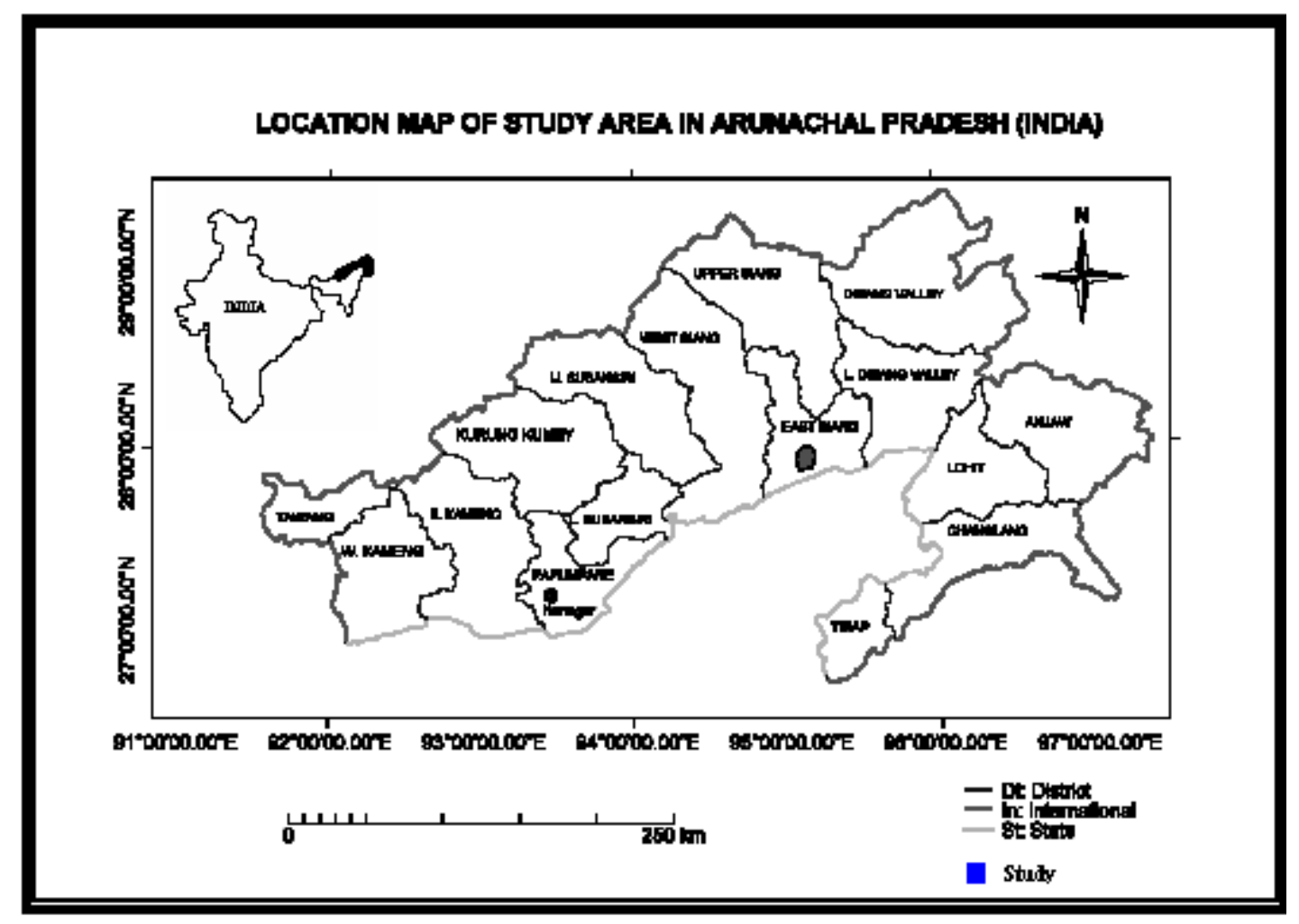

Figure 1: Location map

\section{Objectives}

The basic objective of present investigation is to study the linkages between bio - resources and the livelihood of Adi tribes of Mirem village, Arunachal Pradesh (India). It would also highlight the significance of bio-resources in the economy, material culture, food habits, ethnomedicine and other socio-religious requirements of the people. 


\section{Materials and methods}

The topographical maps published by the Survey of India (1974 - 77) have been used to prepare the location map of the study area. Data regarding the demography and socio economic facilities have been taken from the census $(1991,2001)$ and reports of Department of Economics and Statistics located at Itanagar. Scientific names of various plants and animals have been identified while consulting the standard taxonomic literature and experts from Department of Botany and Zoology, Rajiv Gandhi University, Itanagar and finally verified at herbarium of Botanical Survey of India (BSI), Arunachal Field Station, Itanagar. The Zoological name of the animal species were consulted at museum of Zoological Survey of India, Itanagar and finally verified with the standard literature. $100 \%$ survey of the sample village (Mirem) was conducted through suitable structured questionnaires. Information collected through questionnaires has been supplemented by narration of elders, oral interview and collection of specimen for deriving the primary data.

\section{Observation/Finding}

\section{Bio-resources and economic activity}

The economy of tribal people is largely based on the bio-resources. Their economic conditions mainly depend on the form of agriculture that they practice. Agriculture contributes an important share in the economy of these people. The nature of the terrain has forced them to follow both Jhum/shifting cultivation and Wet Rice Cultivation. Jhum fields lies away from the villages within a radius of $2-3 \mathrm{~km}$ on the convenient slopes of the hills. Nowadays a tendency to move towards lower areas is remarkably observed because of modern facilities and scope for terracing and irrigation. But, still Jhum is the common agriculture system practiced by the people. Wet rice cultivation is mostly found in the lower reaches of the area where there is almost flat surface. The important crops grown in the jhum field and wet rice field are Rice, Maize, Millets, Oilseeds, Potato, Ginger, etc. The agricultural productivity in the area is low, which can be attributed to the old traditional way of agricultural practice with indigenous implements. Collection of forest products, fishing and hunting also form a part of their economy. Shifting cultivation is an integral part of tribal culture. Shifting cultivation grows out of a particular mental outlook of the tribal people and affects all the other spheres of their cultural life. Shifting cultivation is firmly rooted in the religion and mythology of tribal people. They largely depend on shifting cultivation, which has a strong utilization linkage with the natural resources. Food gathering is a supplementary source of livelihood for the people. They depend on the forests for the requirements of vegetables, fruits, barks, edible plants and leaves, etc. Some of the forest products are collected throughout the year while some others are collected for six months only. Collection of edible food items from the forest is done to supplement the shortage of food requirements. Collection of leafy vegetables, mushrooms and other edible items are mainly done by the woman, which is accompanied by their children. Women are considered as the most efficient in collection of vegetables. They have an instinct to locate the place where 
an edible tuber is available or from where they can get some vegetables. The collection of fruits, roots and nuts are done by both male and female. Fruits are collected in particular seasons. Hunting is one of the important aspects of their food quest. Hunting is mostly done when they are free from engagements in their fields. The animals hunted are Deer, Bear, Monkey, Wild boars, Elephant, Tiger, etc. The thick forest around the settlements compel them to pass through deep jungle and the urge for self defence mechanism against the wild life had made them to become good archers. As such hunting became part of their life and through this they supplement their shortage of food supply. Fishing is also an important part of their economy. Fish form an important item of their diet. Fishing is done either by the community as a whole or by individuals. The rivers or streams of the area are endowed with varieties of fresh water fishes. Besides, fish farming in the ponds provides gainful employment to the people and contributes in the generation of income.

\section{Bio-resources and material culture}

The material culture of the village is largely dependent on the surrounding natural bio-resources. The climatic condition and edaphic conditions of the area facilitate luxuriant growth of different species of Bamboo, cane and reed that provides raw materials for construction of their house as well as other essential articles of their daily use like basket, bag, cap, etc. The materials are collected from the surrounding forest. The neighbouring jungle and forests provide the materials for construction of house such as bamboo, cane, thatch / hay, palm leaves, wood, etc. except few cemented buildings. The houses are made with the help of wood beam and bamboo structures. Wood is used in the form of posts for which tall, straight trees are cut and the branches and barks are removed. Different varieties of bamboo are used for different purposes. Cane is used to tie the pieces of bamboo and timber together. The roof is thatched with dry tek anne (Livistona jenkinsiana) and ammung (Erianthus sp.) The whole house is a work of bamboo and wood, bamboo sheets forming the floor and the wall and the wooden logs serving as the main pillars over which the structure of the house is raised. Almost all houses are made in rectangular form having two or three doors according to the individual will and fashion. The doors have wooden ladder leading to the ground. The most important feature is the fire place (meram). Over the fire hearth (perap) hangs a square-shaped bamboo shelf used to dry meat, fish, etc. Meram is prepared with the help of bamboo, wood, soil and cane. Some of the varieties of bamboos viz. Dendocalamus hamiltonii, Arundinaria sp., Bambusa tulda, and B. pallida are used for wall, floor and ropes for binding the poles. House is decorated with skulls of Mithuns, jaws of Pigs and wild boars on the wall. The regum (pigsty) is separated by a small platform outside the house. The regum is also constructed with the help of bamboo, wood, cane, and palm leaves. The space between the floor and ground is used to keep Pigs. Granaries (kumsung) are constructed few meters (10-15 m) away from the main village for protection against fire. Present investigation has revealed that all the houses are constructed with the help of natural bio-resources which are collected from nearby forests. Details of the various bio-resources used in the construction of house are given in table 1. 
Table 1: Different species of Bamboo, Cane and Wood used for House Construction

\begin{tabular}{|c|c|c|}
\hline Local Name & English Name & Scientific Name \\
\hline \multicolumn{3}{|l|}{ BAMBOO } \\
\hline Dibong & Jeti Mistenga & Bambusa tulda Roxb. (Poaceae) \\
\hline Baluka & Bhaluka Barua & Bambusa balcoa Roxb. (Poaceae) \\
\hline Epo & Kako Pacha & $\begin{array}{l}\text { Dendocalamus homiltonii Ness \& Arn ex Munro } \\
\text { (Poaceae) }\end{array}$ \\
\hline Homing & -- & Arundinaria sp. (Poaceae) \\
\hline \multicolumn{3}{|c|}{ RATT AN/CANE } \\
\hline Yoyi & Lejai & Calomus floribundus Griff. (Arecaceae) \\
\hline Takat & Raidang & Calomus flagellum Griff. (Arecaceae) \\
\hline Esong & Sundi & Calamus guruba B uch-Hum. (Arecaceae) \\
\hline Jeying & -- & Calamus tenuis Roxb. (Arecaceae) \\
\hline \multicolumn{3}{|c|}{ TREE (Wood) } \\
\hline Eyum & Bola & Morus laevigata Wall. (Moraceae) \\
\hline Silok & Hollock & $\begin{array}{l}\text { Terminalia myriocarpa Van Heurck \& Mull. Arg. } \\
\text { (Combretaceae) }\end{array}$ \\
\hline Nahar & Nahar & Mesua ferrea L. (Clusiaceae) \\
\hline Gomari & -- & Gmelina arborea Roxb. (Verbenaceae) \\
\hline Hileng & Borpat & Ailanthus grandis Frain(Simaroubaceae) \\
\hline Hepop & Hatipoila & Fterospermum acerifolium (L.) Wild (Sterculiaceae) \\
\hline Kebo & Khokon & $\begin{array}{l}\text { Danbanga grandiflora (Roxb. ex DC.) Walp. } \\
\text { (Sonneratiaceae) }\end{array}$ \\
\hline $\mathrm{Heri}$ & Jutuli & Altingia excelsa Noronha (Hamamelidaceae) \\
\hline Simul & Seveal & Bombax ceiba L. (B ombacaceae) \\
\hline
\end{tabular}

Source: Divisional Forest Office, Pasighat

The various species of bamboo mentioned in the table 1 are used for floor and wall of the house. It is also sliced into small pieces to tie the roof of the house. Rattan species are used as rope to tie the roof and poles. Sometimes the leaves are used as thatching material. The trunks of the trees are used for pillars and poles of the house. Nowadays wooden planks are used for both wall and floor. There are many household articles, which are made of wood, leaves, bamboo, cane, animal bones and skin, etc. These items are collected or gathered from the forest resources. The household materials like handicraft, utensils etc. used by the people are given in Table 2.

Table 2: Various Forest Products used by Adis in sustaining their Domestic Livelihood System

\begin{tabular}{|l|l|l|l|}
\hline Local Name & \multicolumn{1}{|c|}{$\begin{array}{c}\text { English } \\
\text { Name } \\
\text { Bamboo cup }\end{array}$} & Material use & \multicolumn{1}{c|}{ Purpose } \\
\hline Alo-Lodung & $\begin{array}{l}\text { Bamboo } \\
\text { tube }\end{array}$ & Bamboo & $\begin{array}{l}\text { It is a bamboo tube of one internodes and } \\
\text { used as a cup for drinking Apong }\end{array}$ \\
\hline Ambin dupung & Container & Bamboo & $\begin{array}{l}\text { It is a Bamboo tube used as a paddy } \\
\text { container. The open mouth is provided with } \\
\text { section of bamboo lid and a cane handle. }\end{array}$ \\
\hline
\end{tabular}




\begin{tabular}{|c|c|c|c|}
\hline Apo-petok & $\begin{array}{l}\text { Bamboo } \\
\text { tube } \\
\text { Bamboo jug }\end{array}$ & Bamboo/Cane & $\begin{array}{l}\text { It is small Bamboo tube with a lid of } \\
\text { Bamboo section. It serves the purposes of } \\
\text { storing Apong and other things. } \\
\text { This basket is provided with a cane loop } \\
\text { near the open end and with a hole at the } \\
\text { closed end. The hole at the bottom is } \\
\text { provided with a cane stopper to pug it } \\
\text { when required during filtration of millet } \\
\text { beer. It is mainly use during the } \\
\text { preparation of millet beer. }\end{array}$ \\
\hline Egin & $\begin{array}{l}\text { Winnowing } \\
\text { pan } \\
\text { Container }\end{array}$ & $\begin{array}{l}\text { Bamboo/Cane } \\
\text { Bamboo/Cane }\end{array}$ & $\begin{array}{l}\text { It is made of Bamboo. It is used for } \\
\text { carrying food grains and storing food } \\
\text { grains and other things. } \\
\text { It is made of flat Bamboo strips and the } \\
\text { border is tied with cane. It is used to } \\
\text { separate from the grain and keeping } \\
\text { vegetables etc. } \\
\text { It is used as a basket for storing rice etc. }\end{array}$ \\
\hline $\begin{array}{l}\text { Apong } \\
\text { Perop/Ape }\end{array}$ & Basket & Bamboo & $\begin{array}{l}\text { It is used for storing fermented rice from } \\
\text { which Apong (rice beer) is prepared. }\end{array}$ \\
\hline $\begin{array}{l}\text { Epu } \\
\text { Ebong }\end{array}$ & $\begin{array}{l}\text { Mat } \\
\text { Rain shield }\end{array}$ & $\begin{array}{l}\text { Bamboo/Cane } \\
\text { Bamboo/Tpko- }\end{array}$ & $\begin{array}{l}\text { It is used for drying cereals, rice grains } \\
\text { either in the sun or over the hearth. } \\
\text { It is used as a rain shield. }\end{array}$ \\
\hline Megap & Tong & $\begin{array}{l}\text { palm } \\
\text { Bamboo/Cane }\end{array}$ & $\begin{array}{l}\text { It is used for picking up of fire and other } \\
\text { materials. }\end{array}$ \\
\hline Penyo & Spoon & $\begin{array}{l}\text { Bamboo } \\
\text { wood/cane }\end{array}$ & It is used for cooking purpose. \\
\hline $\begin{array}{l}\text { Ebar } \\
\text { Hobuk } \\
\text { Toyi }\end{array}$ & $\begin{array}{l}\text { Basket } \\
\text { Scabbard } \\
\text { String }\end{array}$ & $\begin{array}{l}\text { Cane } \\
\text { Wood/cane } \\
\text { Cane }\end{array}$ & $\begin{array}{l}\text { It is used for carrying fire wood etc. } \\
\text { It is used for keeping dao, knife \& sword. } \\
\text { It is used for weaving carrying materials } \\
\text { and for carrying the child. }\end{array}$ \\
\hline Dumlup & Cap/hat & Bamboo/Cane & $\begin{array}{l}\text { It is cane hat, finely woven which is } \\
\text { decorated with bear skin and wild boars } \\
\text { tooth. }\end{array}$ \\
\hline Sotka & String/rope & Bamboo/Cane & $\begin{array}{l}\text { It is like a jute rope but made of } \\
\text { cane/Bamboo for tying Mithun, Cow and } \\
\text { G oat etc. }\end{array}$ \\
\hline Tali & & & $\begin{array}{l}\text { It is used by men folk for carrying food and } \\
\text { basic needs. }\end{array}$ \\
\hline Kurpyak (Mat) & Mat & $\begin{array}{l}\text { Bamboo/ } \\
\text { (TakoTrees) }\end{array}$ & It is used for sleeping and seating. \\
\hline Doket & $\begin{array}{l}\text { Ginning } \\
\text { Machine }\end{array}$ & wood & $\begin{array}{l}\text { It is used for ginning locally produced } \\
\text { cotton. }\end{array}$ \\
\hline
\end{tabular}

Source: Data collected by the investigator (Field survey, 2008) 
The Agriculture implements of the people, according to their functions and purpose, may be divided into two categories - (i) Implements and equipments associated with shifting cultivation and (ii) Implements and equipments associated with the wet rice cultivation. The implements associated with shifting cultivation are:

Egin:- $\quad$ This is a big cylindrical basket made of Bamboo split and cane.

$I k:-\quad$ A loop of Bamboo used for scraping up small weeds

Lolom:- $\quad$ It is a stick made from bamboo used for scraping up big weeds.

Sokyap:- $\quad$ It is small basket for carrying rich seeds at the time of sowing or dibbling. It is made of bamboo and cane.

Petkok:- $\quad$ Made of small branches of tree and used during clearing of debris.

Eyok-Sobuk: It is made of bamboo or cane used during clearing and felling of trees.

On the other hand the important implements of wet rice cultivation are Plough ( $\mathrm{Na-ngol}$ ) made of wood, Moi-Nernana, generally used for leveling the soil and clearing the debris. It is made of bamboo and cane. Besides, all the indigenous baskets like egin, epo, epu, ebong, papur are considered very essential during wet cultivation that are made of wood, bamboo and cane.

For hunting and catching animals and birds, people usually used different kind of implements made by them from Bio-resources, like Bamboo, wood, cane, etc. The Hunting implement of the people consists of gun, bow and arrow and other trappers.

Eyyi (Bow): Bow is made of Bamboo and the string is made of a cane.

Epuk (Arrow): Arrow is made of slender Bamboo split with a pointed end.

Yokmo: is another kind of Arrow used for killing wild big animals like Boars, Bear, Tiger, and Elephant etc. Its pointed end is fitted with a triangular piece of iron which is smeared with poison called emo (aconite) made from the roots of kinds of herbs.

$E t k u$ : $E t k u$ is the most common implements of hunting. This is generally used for catching rat, squirrels, birds and other small animals only. The $e t k u$ is prepared from Bamboo; string is especially made from 'tabum' (other type of Bamboo) species. Besides all these there are innumerable devices for trapping birds and animals such as eda, songkit, egum, etpeng, komang, etc.

Bio-resources also play vital role in fishing activities of the people. For fishing they are using varieties of traps made of Bamboo, cane, wood, which are locally known as edir, porang, churi, etkong, kodong, tari. Edir is a trapping implement which is made of Bamboo splinted and tied with the help of cane. Porang is also a trapping tool. Porang is prepared from Bamboo. The upside end of the one meter length Bamboo is splinted into many but the other end kept intact. Then the splinted portion is prepared with the help of splinted tabum (other kind of Bamboo species) in such a way that it expands and make an easy passage for the fish to enter 
in the Porang. The shape of Ponang is conical. Huri is bigger type of Porang which is prepared from Bamboo. Tari is one form of Porang. It is prepared by inserting thorny plant leaves so that when fishes enter the Porang the thorny leaves / plants obstruct the fishes from coming out of it. Kodong is a conical shape trappers made of Bamboo and cane used by women folk. Bokong is angling stick extracted from forest i.e. from a Bamboo species known a homing (Arundinaria sp.). During sibok (river diversion) lots of hardwood and leaves of plants and plantains (kolung) are collected for diverting the river. After diverting the river, if the river is not completely dried-up, then the leaves, barks and fruits of plants (mostly the roots of Derris scandens Benth \& bark of Aesculus assamica Griff.) are used to poison the fish locally known as Tamu. Here barks of poisonous plants are used to poison the fishes for easy catch. There are many poisonous plants, the bark of which are used in this method namelyTanir, Taki-sidik, Ripik, Reliom, etc. There are also many toxic plants namely-Marshang (Spilanthes oleracea), Diku-Tamu (Amphineuron opulentum (Kaulf) Holttum, Onger (Zanthoxylum rhetsa), Muyum, etc. used for fish poison.

\section{Bio-resources as food and ethnomedicine}

Other than the traditional food items of modern man, like the rice, wheat, millets, etc they have a treasure house of knowledge about potential food plants from the surrounding forests. These includes leaves, stems, bark, roots, fruits of wild plants and a number of animals and insects gathered as food items. The area is very rich in various types of edible and non-edible items found abundantly in the nearby jungles. Nature has provided plenty of edible plants from which leaves, roots, fruits, flowers, seeds, tuber, etc. are taken as food. They collect those edible plants for their own consumption and other uses. If there is any excess quantity of collected materials, they sell those in the market or exchange with some other essential items of daily needs. The various edible vegetables collected from the forests are bamboo shoot (Dendrocalamus hamiltonii Ness \& Arn. ex. Munro), wild banana flowers (Musa balbisiana L.A Colla), Onger (Zanthoxyllum rhetsa DC.), Oyik (Pouzolzia benettiana Weight), Ongin (Clerodendrom colebrookianum Walp.), Rori (Piper pedicellatum C.DC.), Enge (Colocasia esculenta (L) Schott.), etc. Mushroom (Termitomyces sp. Cantherallus sp. Schizophylum sp., pleurotus Pulmonarius, Auricularia sp.) locally known as Tatar are seasonally collected and many more edible plants which are available but scientifically not known. They also eat number of fruits that are collected from the forest such as Tagung (Magnifera sylvatica Roxb.) Tapir (Phoebe sp.), Anke (Unidentified), Hillum (Canarium strictum Roxb.), Tadar (Myristica fragrans Houtt.), Tak-api (palm fruits), etc.

Forest is the only source for hunting animals and birds. But hunting is never considered as an occupation. On the other hand it gets more importance as an obligatory recreation especially during some rituals and festivals, when it is performed collectively. Forest of the area provides wide range of animals of different species. Some animals such as Tiger, Wolf and Fox are not killed and consumed. These animals are killed only when they cause danger to the human beings and domesticated animals. Sometimes, these animals kill mithun (Bos fontalis), cattle and pig, etc. The other species of animals commonly eaten by the people includes Deer, Bear, Wild Boar, Monkey, Squirrel, Rat, Porcupine, Pangolin, Rabbit, Elephant, etc. Besides, there 
are many domesticated animals which supplement the meat requirements of the people like Mithun, Pig, Buffalo, Cow, Goat, etc.

Table 3: Wild animals eaten by people

\begin{tabular}{|c|c|c|}
\hline Local Name & English Name & Scientific Name \\
\hline Sidum & Deer & $\begin{array}{l}\text { Muntiacus muntjak } \\
\text { Zimmerman }\end{array}$ \\
\hline $\begin{array}{l}\text { Sira } \\
\text { Situm }\end{array}$ & $\begin{array}{l}\text { Wild B cars } \\
\text { Bear }\end{array}$ & $\begin{array}{l}\text { Sus scrofa Linnaeus } \\
\text { Sclenarctos thibetonus (G. } \\
\text { Cuvier) }\end{array}$ \\
\hline Sibe & Monkey & $\begin{array}{l}\text { Macara assamensis } \\
\text { McClelland }\end{array}$ \\
\hline $\begin{array}{l}\text { Bo-Bui } \\
\text { Shipit }\end{array}$ & $\begin{array}{l}\text { Porcupine } \\
\text { Pangolin }\end{array}$ & $\begin{array}{l}\text { Hystrix cristata Linnaeus } \\
\text { Manis pentadactyla Linnaeus }\end{array}$ \\
\hline $\begin{array}{l}\text { Libo } \\
\text { Taka /Keka }\end{array}$ & $\begin{array}{l}\text { Squirrel ( Big size) } \\
\text { Squirrel (Small) }\end{array}$ & $\begin{array}{l}\text { Dremomys lokriah Hodgson } \\
\text { Funambulus pennont } \\
\text { Wrouhgton }\end{array}$ \\
\hline Bungka & Wild Rat & $\begin{array}{l}\text { Ratus-radus Fischer de } \\
\text { Waldheim }\end{array}$ \\
\hline
\end{tabular}

Source: Information collected by investigator

Birds are elegant creatures for the Tribal societies. They hunt birds for various purposes such as to supplement diet with flesh, to procure beaks for decoration in the headgear and to test and develop hunting skills. In fact, hunting birds is a fascination to them. They are predominantly meat eaters and for procuring their meat, they largely rely on hunting. Birds are one of the major attractions to the people for hunting. Various birds eaten by them are wild fowls, hornbills, parrots (small size) (peke), Bulbul, Pigeon, Myna, Dove, etc. Birds like vulture, Sparrow, Crow, Owl are restricted for consumption to the people.

Table 4: Some common bird species eaten by the Adi tribes

\begin{tabular}{|l|l|l|}
\hline \multicolumn{1}{|c|}{ Local name } & \multicolumn{1}{|c|}{ Common name } & \multicolumn{1}{c|}{ Scientific name } \\
\hline Pehik & Hombill & Buceros bicomis Linnaeus \\
Pehin & Jungle fow & Gallus gallus Linnaeus \\
Pehi & Pigeon & Columba fusciata Say \\
Petho & Wood pecker & Picus canus Gmelin \\
Pi-ak & Large Billed Crow & Corms macrorhynchos \\
& & Wagler \\
\hline
\end{tabular}

Source: collected by investigator

Fish are beautiful aquatic creatures that form an important part of human diet due to richness in protein, vitamins and essential oils. Fishes are found in a variety of water bodies ranging from stagnant ponds to flowing rivers or streams. The area has diversity in different species of fishes. Different species of fishes eaten by the people are locally known as Talu, Ngopi, Tageng, kadang, Horche, Ribi, Tasum, take, etc. As per the fishery department the following species of fishes are found in the area Rohu (Labeo rohita), Labeo pangsu, Labeo sp., 
Glyptothrox sp., Garra sp., Abriricthes sp., Psyudochenies sp., Psilorhynchoides sp. $n o b$, eel (Anguilla japonica), prawn (Panoles sp.), crab (Cancer sp.), etc. The surrounding forest provides various species of insects for consumption. Fish resource is declining in the village and adjoining areas since it is felt that there were more fishes in the past than now. Decline in fishes are because of rise in human population and unscientific fishing by blasting \& poisoning streams with chemicals such as bleaching powder and use of generator. Besides all these the people also eat different kinds of insects seasonally. During winter season people collect Tari (Stinkbug) (Poisonous Maculiventris) from the banks of rivers. The other insects like grasshoppers, red-ant, etc. are eaten occasionally.

Above mentioned food items reveals that bio-resources form an important part of their diet. Therefore, it can be said that they are very much dependent on the bio-resources. These edible items are important for their livelihood and also for their very existence.

\section{Ethnomedicines}

Ethnomedicine is the belief and practice relating to health and diseases, which are products of indigenous cultural knowledge of the particular communities. Some notable progress has been made in the field of ethnomedicinal research on the tribes of Arunachal Pradesh by various scholars during last two decades and still many tribes are awaited to be explored ethno biologically in the eastern Himalayan region. The Adis of Siang region use their traditional knowledge in health care system where herbs, plants and roots of some trees and plants locally available are used for curing the ailment. They have indigenous method of treatment for different kinds of diseases with the help of local herbal medicines. They also use body parts of animals such as antelopes, bear, etc. for curing diseases of orthopedic, stomach, and liver pain etc. The common diseases what occuring in the village are dysentery, fever, malaria, jaundice, cough, fracture, etc. Villagers of the remote localities are still relaying their traditional medicines for the alleviation of the local ailments. They mostly use herbals and sometime an admixture of plants, animal and mineral substances coupled with local rituals. Some important medicinal plants used by the Adis for curing different diseases are given in the table 5 .

Table 5: Medicinal plants and mode of use

\begin{tabular}{|l|l|l|l|}
\hline \multicolumn{1}{|c|}{ Scientific Name } & \multicolumn{1}{|c|}{$\begin{array}{c}\text { Local } \\
\text { Name }\end{array}$} & \multicolumn{1}{|c|}{ Disease } & \multicolumn{1}{c|}{ Mode of use } \\
\hline $\begin{array}{l}\text { Terminclia } \\
\text { bellevica } \text { Roxb. }\end{array}$ & Lokyo & $\begin{array}{l}\text { Cold, cough, } \\
\text { fever }\end{array}$ & $\begin{array}{l}\text { Grind it in water then keep it soaked in } \\
\text { water for at least 2 (two) hours, then } \\
\text { drink the water. It is taken 2 to 3 times } \\
\text { in empty stomach. } \\
\text { Paste of the leaf is applied on forehead } \\
\text { for cooling purpose. Leaves are eaten } \\
\text { raw during stomach pain and dysentery. }\end{array}$ \\
$\begin{array}{l}\text { Centella asiatica } \\
\text { (L) Urban }\end{array}$ & Kiling-kiro & $\begin{array}{l}\text { Gastric, } \\
\text { stomach, } \\
\text { dysentery }\end{array}$ \\
\hline $\begin{array}{l}\text { Aristolochia indica } \\
\text { L }\end{array}$ & Hinger & $\begin{array}{l}\text { Srake bite, skin } \\
\text { disease }\end{array}$ & $\begin{array}{l}\text { The whole parts of plant are grind and } \\
\text { consumed. }\end{array}$ \\
\hline
\end{tabular}




\begin{tabular}{|c|c|c|c|}
\hline Coptis teeta Wall. & Finglo & $\begin{array}{l}\text { Malaria, fever, } \\
\text { Jaundice }\end{array}$ & It is consumed with water. \\
\hline $\begin{array}{l}\text { Zingiber zerambet } \\
\text { (L) Smith }\end{array}$ & Kekir & $\begin{array}{l}\text { Stomach, } \\
\text { Vomiting, } \\
\text { Diarrhea }\end{array}$ & $\begin{array}{l}\text { It is a tuber. It is consumed for curing } \\
\text { pain or ache in stomach. }\end{array}$ \\
\hline $\begin{array}{l}\text { Smilax perfoliata } \\
\text { Lour. }\end{array}$ & $\begin{array}{l}\text { Domgal- } \\
\text { Engin }\end{array}$ & Fracture & This plant is use for curing fractures. \\
\hline $\begin{array}{l}\text { Tinospora } \\
\text { cordifolia } \\
\text { (Willd) Miers. Ex } \\
\text { Hook f \& Thoms. }\end{array}$ & $\begin{array}{l}\text { Kynie- } \\
\text { rimong }\end{array}$ & Fracture & Paste and applied on the fracture part. \\
\hline $\begin{array}{l}\text { Zonthoxpllum } \\
\text { rhetsa DC }\end{array}$ & & & \\
\hline & Notke & $\begin{array}{l}\text { Gandhibug/ } \\
\text { Tori poisoring }\end{array}$ & $\begin{array}{l}\text { Roots are crushed into paste and } \\
\text { consumed with water. }\end{array}$ \\
\hline $\begin{array}{l}\text { Gleditia assamica } \\
\text { Bor }\end{array}$ & Dikang & Skin disease & $\begin{array}{l}\text { Fruits are grinded and used as soap for } \\
\text { skin disease. }\end{array}$ \\
\hline $\begin{array}{l}\text { Dendrocalamus } \\
\text { strictus Nees }\end{array}$ & $E-a-A s h i k$ & $\begin{array}{l}\text { Bamboo } \\
\text { injuries, wound } \\
\text { or cut }\end{array}$ & Used in blood clotting. \\
\hline $\begin{array}{l}\text { Kalanchoe } \\
\text { pirnata }\end{array}$ & Nevi-nelum & Burn & $\begin{array}{l}\text { Juice of leaves is applied on burnt parts } \\
\text { of the body. }\end{array}$ \\
\hline Lucas aspera & Ekri-Sipyak & $\begin{array}{l}\text { Nose bleeding, } \\
\text { ear ache }\end{array}$ & $\begin{array}{l}\text { Leaves are grinded and juice is } \\
\text { extracted. Extracted juice is taken with } \\
\text { water. }\end{array}$ \\
\hline
\end{tabular}

Source: Collected by investigator

\section{Socio-religious life and bio-resources}

There is a close relationship between forest and the religious practice of the people. They believe that there is some super natural power in everything. The natural object like mountains, hills, rivers, ponds, the sun, the moon, the earth, etc. are possessed by spirits. Donyi-Polo (The God Sun and Moon) are the main religion followed by the community of the area. Maximum numbers of people are the followers of Donyi-Polo. Besides, there are people who believe in other religion. According to the myths of the Adis, there are many deities or God to control the various parts of universe, such as Sedi-Melo-God of earth and sky, Tusin-RodongGod of forests and Rivers, etc. The living things like trees, plants, bushes, birds, animals, etc. are all around the village situated amidst forest. The people are god-fearing and they believe that every event in their life is guided and controlled by different kinds of spirits. In present study area there are some specific plants, such as tatkeng, tapi, ta-ok, tuduk raksak, tan, etc. which plays significant role in their religious life. Similarly, ridin a creeper also plays significant role in their socio-religious life. In every religious ceremony they utilize this creeper to protect themselves from the attack of evil spirits. According to their traditional belief all the unwanted spirit are afraid of ridin and kekir (ginger sp.).

The Adis being tribal people depend on the bio-resources for socio-religious life. They depend on nature for their fortunes and misfortunes. To avert misfortunes and to bring prosperity to 
every individual, families and to the society as a whole people celebrate many seasonal festivals like solung, etor, unying-aran, tapu, mopun, etting etc. In order to celebrate these seasonal festivals to appease the God and Goddess they use bio-resources such as plants, leaves, stems, etc. to make altars for the deities. Among the forest resources or produce, the tan, ekkam, toti, kapyum, dibang, tapi, taking, tuduk, raksak are collected and used. To erect sacrificial altar for Mithun and Pig, the trunk of tuduk, sirang, rami trees are collected. Again to prepare the altars for sacrifice or for offering, bamboo species like tabum, eyom, e-e are collected from the forest and useas rope to bind the altars. Sometimes ogik a climber is also used as rope. There are also other plant species such as noki, bumlo, Taje, the skin of which are used as rope. To make the offerings some animals are also used like keka, libo (squirrels), bungka (Rat) etc. The above mentioned Bio-resources are used in the celebration of festivals to bring prosperity to the individual, families and also to the whole community.

In the socio-religious life of the people some performers namely-kebang abu (The kebang man), solung, ponung or ettor delong, the narrator of human evolution, origin of plants, animals, mankind, soil, air, water, etc and last one is Ayit-Miri (Priest) which is considered to have super natural power to heal the human sufferings. Kebang is the traditional village council of the Adi community. The role of Kebang is significant in the biodiversity conservation. Uses of bio-resources are under the purview of the Kebang. Illegal extraction of wild bamboo is prohibited by the village council for the sustainable utilization. Modern means of fishing (Blasting, Chemical poison, electric current, etc.) is not allowed as per the norms of the Kebang and violations of these norms are imposed penalty of Rs. 5000 to 10000 . For the sustainable use of these resources community extraction once in a year is done under the strict vigilance of the Kebang and equally distributed to all the households of the village. During illness or suffering, the Ayit-Miri is called and the priest sings whole night and while singing he/she tells the cause of suffering and also the plants and animals to be used for making altar or for sacrifices to be made. In such illness or sufferings many different or varied leaves of plants are used according to the nature of illness and sufferings. Wild bamboo (Nyomrang e-e) and plant species locally known as talo, tapi, takeng, singkang, tatkeng, sirang, tan, takang etc. are gathered in enormous amount and used during rituals and festivals. Rodents locally known as keka, libo, bungka, kosung, etc. are used in various rituals. These plant and animal species are used for erection of altar for offering to the deities, so that they may not inflict or cause any illness to the human being.

It is believed that sometimes when a person is sick just after returning from hunting or fishing, it is the evil deed of Tusin-Rodong (God of Forests and Rivers). To treat the patient and to cure, the priest (Miri) offers or performs a ritual with some special or necessary plants / bamboo extracted from the jungles. The Miri and some senior persons/experts in the community direct the person who collects the required plants and bamboos for the ritual to perform. Accordingly, the person enters the forests and collects the materials as recommended by the priest. Then the ritual is performed and finally the sick person recovers from the illness. Besides there are many more rituals performed with many other product of forest for different types of illness considered to be caused by different deities of the universe. 


\section{Discussion}

The Adi tribes of Arunachal Pradesh largely depend on the bio-resources for their economic life. People's bio-cultural knowledge about the bio-resources has made them sustain their living through the ages. Agriculture is the main occupation of the people. Both wet rice cultivation and shifting cultivation are practiced for their livelihood. The use of indigenous implements and traditional techniques has resulted in lesser agricultural output. However, wet rice cultivation is becoming significant due to better yield in the recent days. Shifting cultivation is still practiced by the people on large scale to meet their day to day requirements. The staple food of the people that includes rice, maize, millet, vegetables, etc. is grown in the agricultural fields for self consumption and commercial purpose. But such a linkage with the forest ecology had led to the degradation of forest resources to a larger extent. There is a need of strong realization through awareness campaigns to immediately check the alarming rate of deforestation in the tribal inhabited areas worldwide. Better alternatives in the form of horticulture, terrace cultivation, agro-based industries can be introduced by taking the ethnic communities in confidence to reduce the rate of deforestation.

Apart from the agricultural practices these people depend on the supplementary source of livelihood for substenance such as food gathering, fishing and hunting. During the shortage of food supply from the agricultural fields they collect fruits, yams, vegetables, edible mushrooms, roots/rhizomes, stems, barks, etc. to supplement it. However, the process of food gathering is becoming a threat to the loss of important plant species. The indigenous way of collecting forest product in not eco-friendly as some people cut the whole tree to collect fruits. Hunting is another supplementary source of sustenance. Deer, Bear, Monkey, Wild boars, Elephant, Tiger, Birds, Rodents, etc. are the important faunal species hunted by these people. Both individual and community hunting are done by them. During festivals deer, wild boar and rodents are hunted on a large scale for the celebration. As a result such species became rare and endangered in the recent decades. Fish is an important diet of the people. People use different indigenous techniques for fishing such as Sibok petnam, porang tonam, edir tonam, etc. which are eco-friendly. But, due to use of chemical poisons and blasting the population of fish has become less in the area. Very recently a new method of fishing in the form use of electric current in the rivers and streams has further decreased the fish population.

The material culture of the people is largely built out of the product of natural bio-resources viz. wood, bamboo, palm leaves, cane, etc. It is observed in about $95 \%$ households the various items are directly collected from the natural bio-resources such as basket, mat, stool, spoon, mug \& jug, bow \& arrow, hunting trap, fishing tools, etc. They also have knowledge of ethnomedicines for curing various diseases. Different parts of plants and animals are used to cure various ailments such as stomachache, headache, joint / fractures, cough / flu, jaundice, dysentery / diarrhea, orthopaedic, eye infection, snake bites, etc. Bio-resources form an important part of the religious life of the people. They worship the nature viz. hills, mountains, rivers, sun, moon, etc as these provide the various requirements of the people. Such old age practices have led to the preservation of natural resources to a greater extent in the past. But, due to influx of modernization they are converting to different organized religions which are fading the ethnic belief systems associated with the nature. The indigenous knowledge system 
can be utilized through active participation of Government and Non-governmental agencies in checking the emerging harsh linkages with the nature. Such an effort can ensure the availability of resources in their vicinity for a longer period of time.

\section{Conclusion}

The study of linkages between bio-resources and human livelihood is significant in understanding the pattern of interaction between the people and their surrounding forests. It is observed that most of the tribal people of Arunachal Pradesh prefer to live in forest environment and for their sustenance they utilize bio-resources of their immediate surrounding with their age-old traditional knowledge and technique. The way of life of the Adi tribes is closely associated with physical environment which form an inseparable component in the ecosystem and thus maintain inseparable relationship with the natural resources. The whole discussion is mostly related to the people and their dependence on the bio-resources for economic, material, social and ritual sustenance. They practice jhum/shifting cultivation for their requirement of food and during the food shortage they collect various edible plant parts from the forest to supplement it. The women folk play significant role in collection of such edible fruits, roots and tubers, leaves, etc. Besides, hunting and fishing are the other supplementary source of livelihood.

They have knowledge of traditional herbal medicine to cure and prevent diseases. Their traditional healing practices are largely dependent on different plants and animal species which are mostly used by few practitioners of the village who have specialized knowledge in ethnomedicines. In addition to the use of bio-resources in material culture, food, medicine and socio-religious life of the people, they conserve bio-resources in their natural habitat through clean forest management system. They narrate myths and legends about certain rare and endangered species of plants and animals at home and in public gathering to educate the younger generation for the conservation and sustainable utilization of biodiversity wealth of their concerned area. They use bamboo, cane, wood, palm leaves, vegetables, etc. for commercial purposes. For instance, bamboo shoots, baskets \& mats, firewood, etc. are being sold in the local market in exchange of money. Forest products had been the articles of barter trade of the people in their neighbouring areas during the past which lost its significance at present due to emergence of market economy.

The present study reveals that for the sake of survival in the area, people use their old age indigenous knowledge where natural bio-resources as well as natural phenomena play an important role in shaping their life and culture. Due to the increase in population leading to the knowledge of market economy the linkages between the people and the bio-resources is gearing up remarkably. Such a study in the tribal inhabited area is essential to create awareness and realization among the forest dwellers about the harsh linkages emerging out of higher level of interaction with the forest ecology. Hence, the paper is significant for the forest dwellers to asses the level of bio-resource utilization and framing strategies for sustainable utilization of forest resources in future continuum. 


\section{Acknowledgements}

The authors are thankful to the Vice Chancellor of Rajiv Gandhi University, Itanagar for encouragement and infrastructure facilities for conducting research. We acknowledge the old people of Adi tribes for providing information regarding the linkages between bio-resources and livelihood. Thanks are also due to our loving parents for the pain they have taken in our brought up and enabling us to contribute research works to the world.

\section{References:}

Nimachow, G \& Yadava, R S. 2006, Linkages between Bio - resources and Human Livelihood: (A Study on the Akas of Arunachal Pradesh), India, The Deccan Geographer, 44(2): 55-66

Roy, S. 1960, Aspects of Padam Minyong Culture, Directorate of Research, Government of Arunachal Pradesh

Nimachow, G. 2003, Akas and their forests: A study on traditional management of forest resources in Arunachal Pradesh, Arunachal University Research Journal, India, 6(2): $79-92$.

Tag, H \& Das, A K. 2004, Ethonobotanical Notes on the Hill Miri tribes of Arunachal Pradesh, India, Indian Journal of Traditional Knowledge 3(1): 80.

Kala, C P. 2005, Ethonomedicinal botany of the Apatani in the Eastern Himalayan region of India, Journal of Ethnobiology and Ethnomedicine 1(11): [http:// www.ethnobiomed.com/content/1/1/11].

Das, A K \& Tag, H. 2006, Ethnomedicinal studies of the Khamti tribe of Arunachal Pradesh, Indian Journal of Traditional Knowledge, India, 5(3): 317-322.

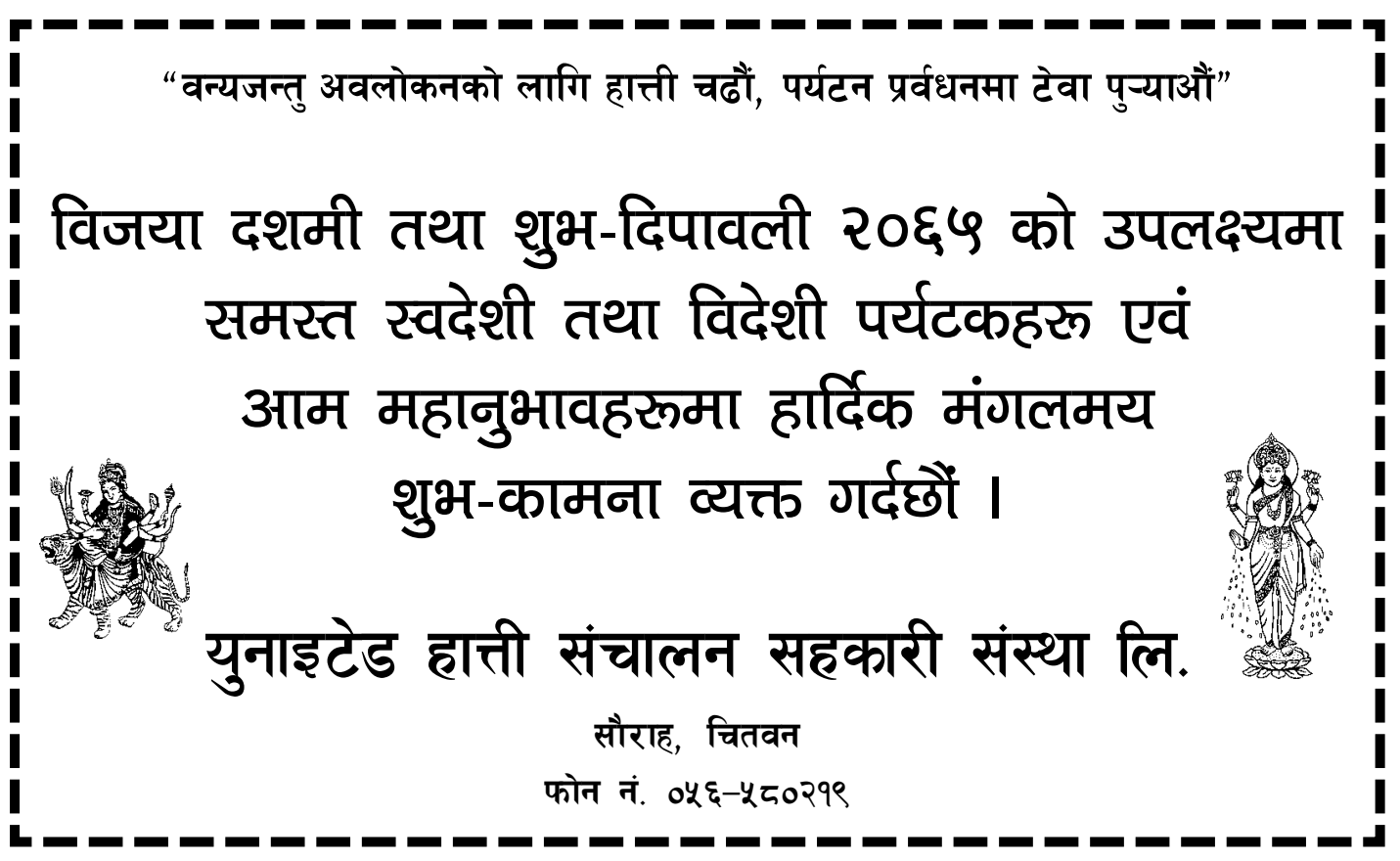

